\title{
ANALISIS PENGARUH PRODUKTIVITAS TENAGA KERJA TERHADAP PENJUALAN PT 3M INDONESIA
}

Oleh : Sugiyarto, SE., MM.

sugiyarto.harto@gmail.com

\begin{abstract}
Abstrak
Produktivitas tenaga kerja tiggi mencerminkan bahwa kinerja perusahaan juga baik. PT.3M Indoneisa adalah satu perusahaan Amerika yang menjalankan usahanya di Indonesia dan bergerak dalam perdagangan. Penulis melakukan penenlitian pada tahun 2001 sebagai bahan untuk skripsi dengan judul Analisi Pengaruh Produkstivitas Tenaga Kerja Terhadap Penjualan PT. 3M Indonesia.

Analisa data tenaga kerja dan penjualan menggunakan data lima tahun dari tahun 1996 sampai dengan tahun 2000. Tahun 2007 produktivitas tenaga kerja turun 5,3\%, kemudian tahun 2008 terjadi peningkatan produktivitas tenaga kerja naik 158,4\% ,dan penjualan naik 23,9\%, hal ini berkaitan dengan perusahaan melakukan efesiensi dengan melakukan pengurangan tenaga kerja mencapai 52,1\% jumlah tenaga tahun sebelumnya. Namun pada tahun 1999 kembali mengalami penurunan produktivitas tenaga kerja sebesar 41,3\%, karena pada tahun 2008 perusahaan melakukan penambahan tenaga kerja. Dan pada tahun 2000 produktivitas tenaga kerja kembali meningkat 250,8\% .dan ada peningkatan penjualan sebesar 42,6\% Hal ini tidak terlepas dari usaha menejemen memangkas tenaga kerja sampai 145,5\% dari jumlah tenaga kerja 211 orang menjadi 145 tenaga pada tahun 2000.

Dari data lima tahun ini dapat peroleh ( $\boldsymbol{r}$ ) korelasi atau hubungan produktivitas terhadap penjualan sebesar 0,85, karena $r>0$, dapat di simpulkan bahwa adanya hubungan positif. Sementara dari analisis korelasi determinasi $(\boldsymbol{k} \boldsymbol{d})$ di peroleh angka sebesar 72,25\% artinya produktivitas tenaga kerja hanya mempengaruhi penjualan sebesar 72,25\%. Sisanya 27,75\% penjualan di pengaruhi oleh faktor-faktor lainnya.
\end{abstract}

Kata Kunci : Produktivitas tenaga kerja tiggi mencerminkan bahwa kinerja perusahaan juga baik

\section{PENDAHULUAN}

\section{Latar Belakang Masalah}

Produktivitas tenaga kerja yang tinggi adalah menjadi tujuan yang ingin di capai oleh manajemen perusahaan. Banyak manajemen perusahaan berfikir bahwa tenaga kerja adalah 
merupakan bagian dari asset perusahaan. Perhatian bisa di wujudkan dalam bentuk pemberian reward bagi karyawan yang berprestasi dan memiliki kinerja yang baik, sehingga bisa memotivasi karyawan yang lainnya berkinerja yang baik. Dorongan dan contoh dari supervisor atau manager di butuhkan dalam sebuah organisasi untuk memotivasi bawahan agar selalu optimis dalam pekerjaannya. Memang tidak mudah mempertahankan agar motivasi dan semangat kerja, di butuhkan pendekatan constructive antara atasan dan bawahan.Pendekatan bisa dalam bentuk metting evaluasi kerja untuk mengetahui hambatan dan masalah yang di hadapi dalam pekerjaan sehari - hari yang mengakibatkan tidak tercapai target yang telah di tetapkan.

\section{Identifikasi Masalah}

Kurangnya informasi yang di terima oleh karyawan mengenai kondisi, lingkungan kerja,sarana pendukung dan peralatan kerja yang tidak memadai bisa menjadi hambatan tercapainya produktivitas tenaga kerja yang berujung pada tidak tercapainya tujuan perusahaan.

Dari uraian di atas penulis mengidentifikasi beberapa poko permasalahan yang di hadapi karyarwan dan perusahaan sebagai berikut :

1. Mengapa produktivitas tenaga kerja rendah?

2. Apa yang harus di lakukan manajemen agar penjualan meningkat ?

3. Sudahkah karyawan bekerja sesuai dengan standart yang telah di tetapkan?

Maju dan mundurnya organisasi dan bisnis perusahaan tidak bisa hanya tergantung pada satu divisi sales dan marketing.

Semua komponen di dalam perusahaan saling terkait dan memiliki peran dan tanggung jawab yang sama sesuai dengan jabatan serta fungsinya.

Bila ada kekurangan dan masalah dalam menjalankan fungsi dan tugas masing-masing maka harus segera di lakukan evaluasi dan hasilnya di jadikan tolak ukur untuk melagkah dan bekerja lebih baik di kemudian hari.

\section{Tujuan dan Manfaat Penelitian}

Tujuan yang ingin dicapai dalam penelitian adalah untuk mengetahui :

1. Tingkat produktovitas tenaga kerja PT 3M Indonesia tahun 1996 - 2000

2. Tingkat penjualan PT 3M Indonesia tahun $1996-2000$

3. Pengaruh produktivitas tenagan kerja terhadap penjualan PT $3 \mathrm{M}$ Indonesia 


\section{Manfaat Penelitian bagi penulis :}

Mempertajam analisa dan wawasan yang rasional dan realistis berdasarkan data-data penelitian.

\section{Manfaat bagi perusahaan :}

Dari hasil penelitian bisa di jadikan dasar untuk pengambilan keputusan berkaitan dengan perencanaan penambahan ataupun pengurangan karyawan.

\section{Pembatasan Masalah}

Karena keterbatasan waktu, penulis membatasi pokok permasalahan pada produktivitas tenaga kerja, di mana yang di maksud tenaga kerja di sini adalah seluruh karyawan yang ada di perusahaan. Sedang penjualan di sini adalah nilai atau hasil penjualan yang di peroleh perusahaan.

Maka dalam penelitian ini di batasi pada "Analisis pengaruh produktivitas tenaga kerja terhadap penjualan PT 3M Indonesia ".

\section{Hipotesis}

Dalam penelitian ini penulis membuat hipotesa dengan dugaan sementara bahwa : “ Jika produktivitas tenaga kerja tinggi maka akan meningkatkan penjualan “

\section{Metode Penelitian}

Dalam penelitian ini penulis menggunkan metode sebagai berikut :

\section{Sumber Data}

a. Data Primer yaitu data yang di peroleh dari sumber yang di jadikan objek penelitian secara langsung

b. Data sekunder yaitu data dari perbandingan antara teori yang di peroleh di bangku kuliah dengan dunia kerja yang sesungguhnya di lapangan

\section{Metode Pengumpulan Data.}

Yaitu dengan wawancara dan meminta data jumlah tenaga kerja tahun 1996-2000 kepada manajer personalia dan manejer pemasaran PT 3M Indoneisa untuk memperoleh data penjualan antara tahun 1996 - 2000 untuk anlisa data penelitian. 


\section{LANDASAN TEORI}

\section{Pengertain Produktivitas}

Setiap perusahaan menginginkan produktivitas tenaga kerja yang dimiliki tinggi, agar tujuan perusahaan untuk memiliki daya saing dan efesiensi di capai .

Menurut Dewan Produktivitas Nasional, definisi dari produktivitas adalah sikap mental yang selalu berpandangan bahwa mutu atau kualitas hari ini harus lebih baik dari hari kemarin dan hari esok harus lebih baik dari hari ini ( Huesin Umar,2000; 19)

Secara umum produktivitas adalah perbandingan antara hasil yang di capai (outpu) dengan sumber daya yang di gunakan (input)

Hasil yang di capai (output)

Produktivitas $=$

SDM yang di gunakan (input)

Produktivitas itu memiliki dua dimensi

1. Dimensi efektivitas yang mengarah pada pencapaian hasil kerja yang maksimal dengan kualitas ynag baik dalam mencapaian target yang telah di tetapkan

2. Dimensi efesiensi yang berkiatan dengan usaha untuk menghitunga perbandingan antara input denganrealisasi bagaimana pekrjaan tersbut di laksanakan

Keterkaitan antara produktivitas, efektifitas, efesiensi dan kualitas

( Husein Umar, 2000, 10 )

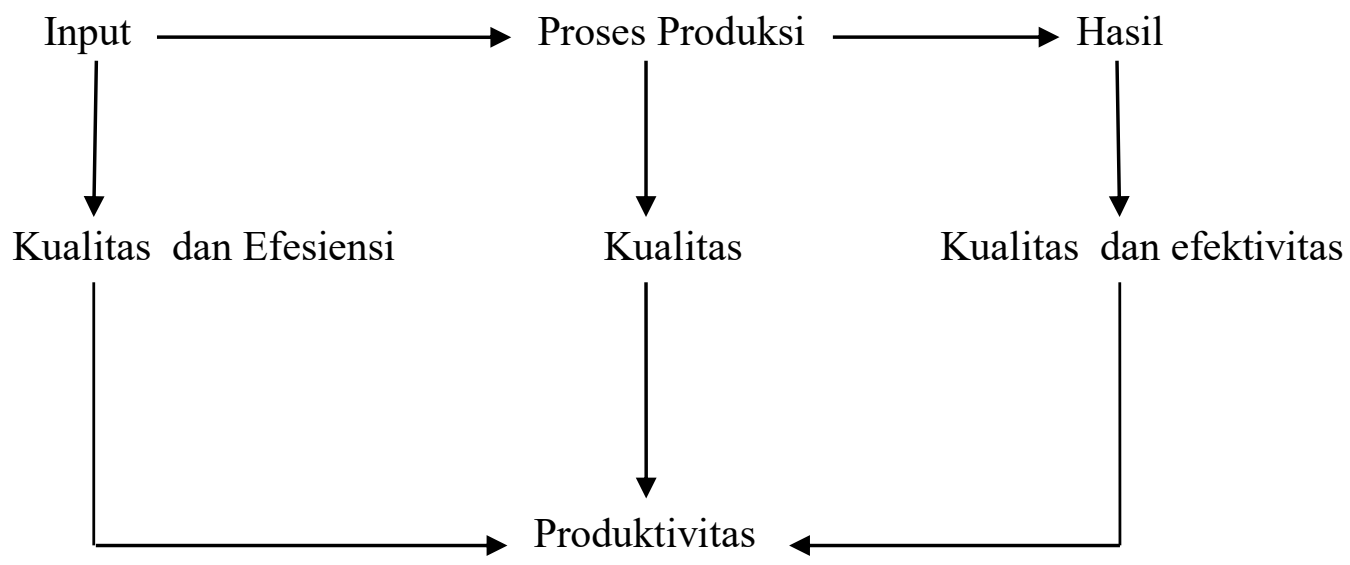




\section{Produkivitas dan Efesiensi Administrasi Publik Dalam MSDM}

Dalam konidis pertumbuhan ekonomi yang lesu secara makro tidak mungkin produktivitas masyarakat tinggi.

Secara tidak langsung produktivitas ini sudah menjadi kepentingan umum, sehingga pemerintah mengapus beberapa lembaga yang di anggap tidak produktif.

\section{Pengukuran Produktivitas}

Keberhasilan seorang manajer di ukur dari tingkat produktivitas yang bisa dicapai oleh yang bersangkutan.

Pengukuran produktivias tenaga kerja menurut ( Husein Umar, $2000 ; 156$ ) sebagai berikut :

Jumlah Penjualan

Produktivitas Kerja $=$

Jumlah Tenaga Kerja

Ada tiga prinsip yang harus di pakai dalam pengukuran produktivitas ( Handoko, $1994 ; 212$ ) :

1. Menetapkan ukuran - ukuran yang di pakai

2. Mengkaitakan rasio produktivitas dengan semua tanggung jawab pekerjaan

3. Meningkatkan produktivitas setiap unit yang di hubungkan dengan tujuan perusahaan.

\section{Faktor Yang Mempengaruhi Produktivitas}

Produktivitas di pengaruhi oleh lima faktor (Faustino Cardoso Gomes, $2000 ; 160$ ) :

1. Knowledge

2. Skill

3. Abilities

4. Attitude

5. Behavior.

Menurut Balai Pengembangan Produktivitas Daerah, ada enam faktor utama yang menentukan produktivitas tenaga kerja :

1. Sikap kerja

2. Tingkat ketrampilan 
3. Hubungan antara tenaga kerja dan pimpinan

4. Manajemen produktivitas

5. Efesiensi tenaga kerja

6. Kewirausahaan

\section{Produktivitas dan Kualitas}

Ada kecenderungan apabila seseorang di dalam melakukan pekerjaan dengan tempo tinggi, orang tersebut akan terburu - buru bahkan cenderung mengabaikan kualitas.

Hal ini tidak akan terjadi kalau setiap pekerjaan ada standart prosedur dan intruksi pekerjaan yang jelas .

Tingkat kesadaran dalam diri karyawan untuk menjaga kualiatas produk juga harus di bangun dan di tanamkan dalam mindset karyawan.

\section{Penjualan}

Untuk mencapai target penjualan yang akan di capai, perusahaan harus membuat strategi. Hal ini perlu di lakukan untuk mengetahui perkembangan perusahaan dari beberapa aspek baik dari prespektif keuangan dan non keungan. ( Amin Wijaya Tunggan, Ak, MBA, Scocard, $2000 ; 4$ )

Keputusan utama dalam pemasaran dalam struktur organisasi sangat di butuhkan untuk mentukan strategi pemasaran yang tepat untuk di gunakan (Kothler, 1997:28 )

\section{Memutuskan Apakah Bergerak ke Luar Negeri}

Banyak perusahaan memutuskan hanya untuk menjual produknya pada pasar domestik, mereka tidak mau repot mempelajari karakteristik pasar di luar negeri.

Namun pada saat pasar di dalam negeri lesu, maka banyak perusahaan tutup karena kehilangan pasar.

Ada empat faktor yang banyak membuat pengusaha tertarik untuk expansi pasar luar negeri

1. Produk yang di hasilkan memiliki daya saing di pasar internasional

2. Basis pelanggannya lebih besar

3. Peluang memperoleh keuntungan lebih besar

4. Mengurangi ketergantungan pada satu pasar. 


\section{Menentukan Pasar Mana Yang akan di Masuki}

Secara umum apabila suatu perusahaan memutuskan untuk beralih keluar negeri, maka proporsi pasar yang akan di peroleh sangat kecil dan hal ini wajar bagi pendatang baru di pasar yang baru juga.

Yang perlu di pertimbangkan adalah tujuan negara yang akan di jadikan sasaran pemasaran produk. Dimana daya tarik pasar suatu negara di pengaruhi oleh faktor geografis, pendapatn, populasi penduduk, politik dna produk yang di tawarkan ( Kothler, 1997; 30 )

\section{Menentukan Bagaimana Memasuki Pasar}

Setelah di putuskan memasuki suatu negara tertentu, maka harus di pilih cara untuk memasarkan produk tersebut.

- $\quad$ Bisa export secara langsung ataupun tidak langsung

- $\quad$ Memberikan lisensi

- $\quad$ Membuka usaha patungan (joint venture)

- $\quad$ Investasi langsung dengan membuka pabrik di negara tujuan.

\section{Menentukan Program Pemasaran}

Perusahaan yang sudah memiliki jaringan pemasaran di luar negeri harus bisa menyesuaikan dengan kondisi pasar lokal.

Menurut Keegan ada enam strategi adaptasi produk dan promosi :

1. Perluasana Langsung yaitu pengenalan produk di luar negeri tanpa perubahan bentuk

2. Adaptasi Produk yaitu melakukan perubahan produk untuk memenuhi selera pasar lokal dari negera yang di tuju.

3. Penemuan Produk Baru yaitu membuat sesutau yang baru yang di sesuikan dengan kebutuhan pasar negara yang di tuju.

4. Promosi yaitu malekukan promosi dengan melalui media yang bisa di gunakan seperti, internet, modia sosial, media cetak ataupun media elektronik.

5. Harga sebagaian besar kendala yang di hadapi ketika perusahaan mulai memperoleh pasar di luar negeri adalah adanya peningkatan biaya yang berdampak terhadap harga jual produk itu sendiri.

Sehingga perusahaan harus menetapkan strategi harga yang baik, maka di butuhkanlah standart harga degan cara

- Menetapkan harga yang sama di semua negara 
- Menetapkan harga berbasis pada pasar pada tiap negara

- Menetapkan harga berbasis biaya di tiap negar

\section{Saluran Distribusi}

Ada 3 mata rantai dalam saluran distribusi menurut (Kothler, 1997; 43 ) sebagi berikut :

1. Kantor pusat pemasaran internasional, yaitu departemen export membuat saluran distribusi dan bauran pemasaran yang efesien.

2. Saluran antar negara yaitu membawa produk ke perbatasan negara dengan melalui perantara misalnya agen . distributor.

3. Saluran di dalam negara asing membawa produk langsung ke pembeli -dan pemakai akhir.

\section{Menentukan Organisasi Pemasaran}

Ada tiga cara dalam menentukan organisasi pemasaran dalam mengelola aktivitas Pemasaran

1. Melalui departemen export

2. Divisi Internasional ( dengan memberikan lisensi)

3. Organisasi global yaitu memberlakukan dunia sebagai pasar global.

\section{DESKRIPSI OBJEK PENELITIAN}

\section{Sejarah berdirnya 3M Indonesia}

3M ( Minning Minesota Manufacturing) merupakan perusahaan multi nasional yang awalnya bergerak dalam bidang pertambangan yang berkantor pusat di St. Poul Amerika. Perusahaan yang mengalokasikan $20 \%$ dari laba yang di peroleh perusahaan setiap tahun ini di alkoasi untuk riset dan pengembangan ,3M ada hampir di seluruh dunia, di Asia ada 3M China, 3M Korea, 3M Taiwan, 3M Malaysia, 3M Japan, di eropa ada 3M German, 3M Italy, 3M UK dan lainnya.

Pada tahun 1975 di motori oleh seorang execituve dari 3M St. Poul dengan pengusaha Indonesia Bapak Soedarpo pemilik Samudera Indoneisa Group berdirilah 3M Indonesia. Produk yang di hasilkan 3M sudah lebih dari 60.000 jenis dan sudah di pasarkan di 200 negara di seluruh dunia. Dan karyawan 3M di seluruh dunia pada tahun 2001 mencapai 37.389 orang. Adapun produk 3M yang di pasarka di Indonesai anatara lain, adhesive tape, healt 
Care Product, Electrical and telecom product, contrcution product / kaca film, fire protection Chemical, acrylic foam tape, scoth brite, overhead projector

\section{Struktur Organisasi PT 3M Indonesia}

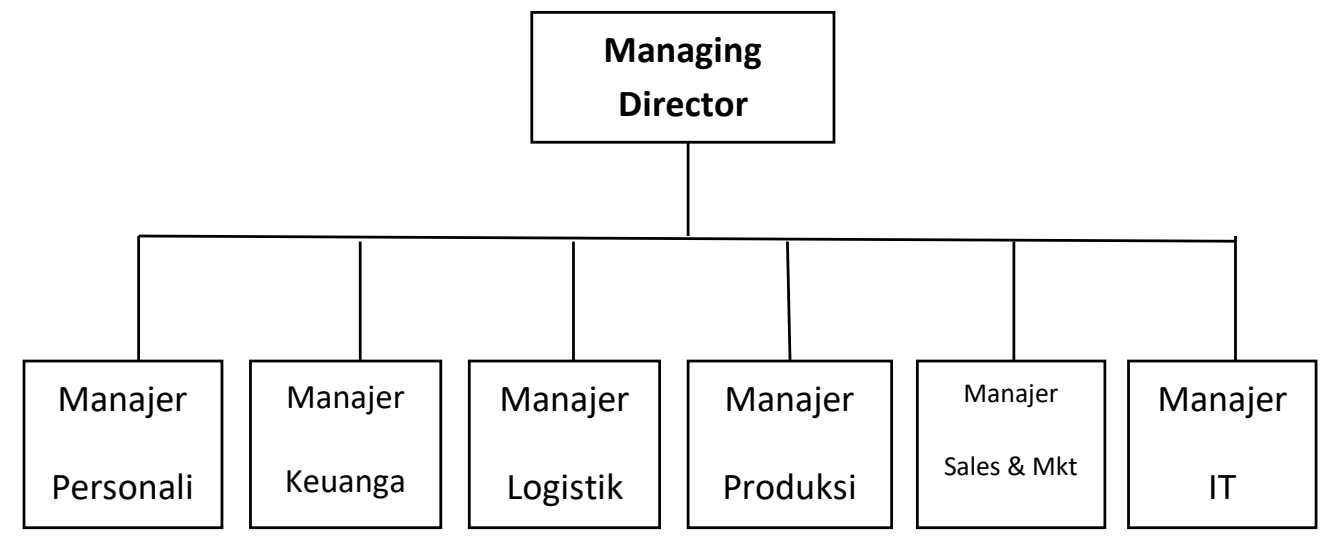

\section{Analisa Data dan Pembahasan}

\section{Analisa Produktivitas Karyawan PT. 3M Indonesia}

Berikut ini adalah data produktiviyas tenaga kerja PT 3M Indonesia dari tahun 1996- 2000.

Produktivitas Tenaga Kerja Tahun 1996 - 2000

\begin{tabular}{|l|c|c|c|}
\hline Tahun & $\begin{array}{c}\text { Jumlah Tenag } \\
\text { Kerja }\end{array}$ & $\begin{array}{c}\text { Produktivitas dalam } \\
\text { Milyar Rupiah (X) }\end{array}$ & \% Pertumbuhan \\
\hline 1996 & 438 & 0,170 & - \\
\hline 1997 & 286 & 0,161 & $-5,4 \%$ \\
\hline 1998 & 137 & 0,416 & $158,4 \%$ \\
\hline 1999 & 356 & 0,244 & $-41,3 \%$ \\
\hline 2000 & 145 & 0,856 & $250,8 \%$ \\
\hline
\end{tabular}

Sumber PT. 3M Indonesia

Karena data tahun 1995 tidak termasuk dalam data analisa data dari perusahaan tidak di peroleh, maka khusus untuk tahun 1996 penulis tidak menghitung dan menganalisa data 1995 di bandingkan dengan data tahun 1996 sehingga pertumbuhan produktivitas tenaga kerja tidak di ketahui. 
Pada tahun 1997 pertumbuhan poduktivitas tenaga kerja mengalami penurunuan sebesar 5,4\% di bandingkan dengan tahun 1996.

Pada tahun 1997 bisnis perusahaan mengalami penurunan karena pelemahan perekonomian dunia khususnya kawasan asean yang berimbas ke Indonesia.

Pada tahun 1998 produktivitas tenaga kerja mengalami peningkatan sebesar $158, \%$ di bandingkan tahun 1997.

Karena pada 1998 perusahaan melakukan efesiensi dengan cara rasionalisasi tenaga kerja. Mencapai $52,1 \%$ dari total tenaga kerja 286 orang menjadi hanya 137 orang tenaga kerja pada tahun 1998.

Kemudian pada tahun 1999 produktivitas tenaga kerja kembali mengalami penurunan hingga $-41,3 \%$ dibanding dengan tahun 1998. Ini di sebabkan keyakinan manajemen perusahaan pada tahun 1999 yakin bahwa bisnis akan terus membaik dan berkembang, sehingga di adakan penambahan karyawan pada tahun 1998.

Dan pada tahun 2000 produktivitas mengalami pertumbuhan sebesar 250,8\% dai bandingkan tahun sebelumnya. Karena menejmen perusahaan melakukan pengurangan tenaga tenaga sebanyak 211 orang atau 145,5\% dari tahun sebelumnya. Sehingga pada tahun 2000 perusahaan hanya memperkerjakan 145 karyawan.

\section{Analisa Penjualan PT 3M Indonesia}

Berikut ini adalah data penjualan PT 3M Indonesia dari tahun 1996 - 2000

\begin{tabular}{|l|c|c|}
\hline Tahun & Penjualan dalam Milyar Rupaih ( Y ) & $\%$ Pertumbuhan \\
\hline 1996 & 44.000 .000 .000 & - \\
\hline 1997 & 46.000 .000 .000 & $4,5 \%$ \\
\hline 1998 & 57.000 .000 .000 & $23,9 \%$ \\
\hline 1999 & 87.000 .000 .000 & $52,6 \%$ \\
\hline 2000 & 124.100 .000 .000 & $42,6 \%$ \\
\hline
\end{tabular}

\section{Sumber PT.3M Indonesia}

Dari data tersebut di atas dapat di jelaskan bahwa dari tahun 1996 - 2000 ada pertumbuhan penjualan. 
Pada tahun 1996 penjaualn mencapai Rp. 44 Milyar, dan pada tahun 1997 naik menjadi Rp. 46 Milyar artiny ada peningkatan pertumbuhan penjualan sebesar 4,5\% di bandingkan tahun sebelumnya.

Sedangkan pada tahun 1988 penjualan mengalami peningkatan sebesar 23,9\% di bandingkan dengan tahun sebelumnya.

Dan berdasarkan data pada tabel penjualan, peningkatan paling tiggi terjadi pada tahun 1999 yaitu sebesar 52,8\% di bandingkan tahun sebelumnya.

Khusus tahun 2000 kalau kita lihat data penjualan secara pada tahun ini angka penjualan adalah paling tinggi di antara penjualan dari tahun 1999-2000.

\section{Analisa Pengaruh Produktivitas Tenaga Kerja Terhadap Penjualan PT.3M Indonesia}

Berdasarkan data produktivitas tenaga kerja dan penjualan tersebut kita bisa membuat analisa untuk mengetahui sejauh mana perngaruh produktivitas tenaga kerja terhadap penjualan.

Berikut adalah data-data yang di jadikan bahan untuk analisis dalan milyar rupiah :

\begin{tabular}{|l|c|c|c|c|c|}
\hline Tahun & $\begin{array}{c}\text { Produktivitas } \\
(\mathrm{X})\end{array}$ & $\begin{array}{c}\text { Penjualan } \\
(\mathrm{Y})\end{array}$ & $\mathrm{X}^{2}$ & $\mathrm{Y}^{2}$ & $\mathrm{XY}$ \\
\hline 1996 & 0,170 & 44 & 0,0289 & 1936 & 7,48 \\
\hline 1997 & 0,161 & 46 & 0,0259 & 2116 & 7,41 \\
\hline 1998 & 0,416 & 57 & 0,1731 & 3249 & 23,71 \\
\hline 1999 & 0,244 & 87 & 0,0595 & 7569 & 21,23 \\
\hline 2000 & 0,856 & 124,1 & 0,7327 & 15401 & 106,03 \\
\hline & $\Sigma \mathrm{X}=1,847$ & $\Sigma \mathrm{Y}=358,1$ & $\Sigma \mathrm{X}^{2}=1,0201$ & $\Sigma \mathrm{Y}^{2}=30271$ & ${ }^{\Sigma} \mathrm{XY}=166,03$ \\
\hline
\end{tabular}

Produktivitas $(X)=$ dalam milyar rupiah

Penjualan $(\mathrm{Y}) \quad=$ dalam milyar rupiah 


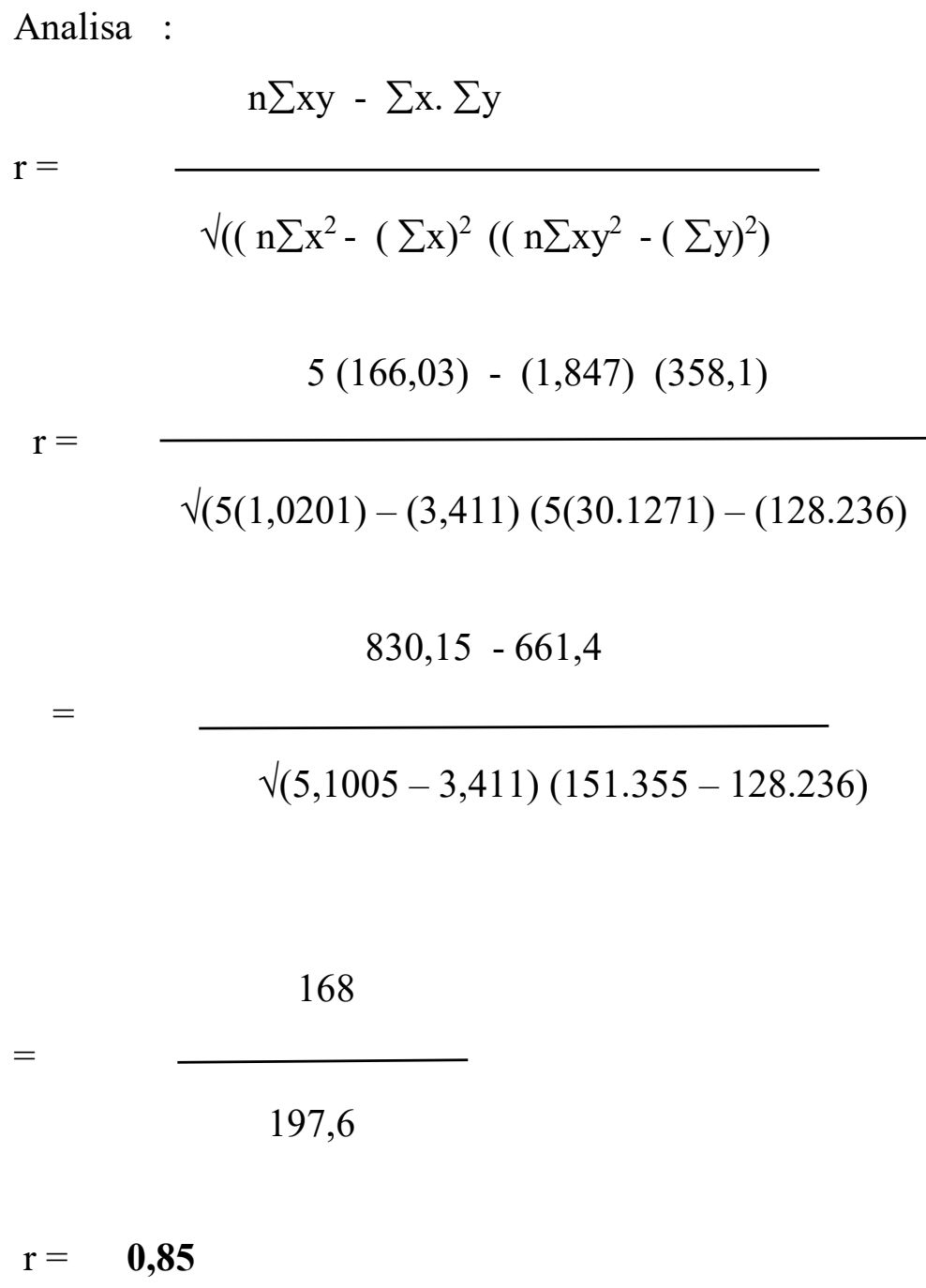

Karena nilai $\mathrm{r}>0$, artinya telah terjadi hubungan positif, dimana semakin besar nilai variable $X$ (independent), maka semakin besar nilai variable $Y$ (dependent)

Sedangakan untuk mengetahui seberapa besar persentase pengaruh antara produkstivitas tenaga kerja terhadap penjualan, maka kita harus menghitung koefesien determinasi sebagai berikut:

$$
\begin{aligned}
\mathrm{Kd} & =\mathrm{r}^{2} \times 100 \% \\
& =0,85^{2} \times 100 \% \\
\mathrm{Kd} & =\mathbf{7 2 , 2 5} \%
\end{aligned}
$$


Dari perhitungan di atas di ketahui koefesien determinasi/Kd adalah 72,25\%, artinya produktivitas tenaga kerja hanya mempengaruhi penjualan sebesar72,25\%. Sedangkan $27,75 \%$ di pengaruhi oleh faktor-faktor lainnya.

Untuk melakukan pengujian korelasi tersebut, maka perlu dilakukan pengujian hipotesa, bahwa $\mathrm{Ho}=0$ atau tidak, $\mathrm{H} 1 \neq 0$ atau memiliki arti. Maka di gunakan pengujian dengan statistik $t$ sebagai berikut :

$$
t=\frac{r \sqrt{ }(\mathbf{n}-2)}{\sqrt{ }\left(1-r^{2}\right)}
$$

Dimana, $\mathrm{dk}=\mathrm{n}-2$

Kriteria pnegujian adalah tolak Ho, jika harga mutlak $\mathrm{t}>$ dari harga $\mathrm{t}$ tabel distribusi. Maka di ketahui :

$$
\begin{aligned}
& \mathrm{N}=5 \\
& \mathrm{r}=0,85 \\
& 0,85 \sqrt{ }(5-2) \\
& \mathbf{t}= \\
& \sqrt{ }\left(1-0,85^{2}\right) \\
& 2,6 \\
& 0,5 \\
& t=\quad 4,9
\end{aligned}
$$




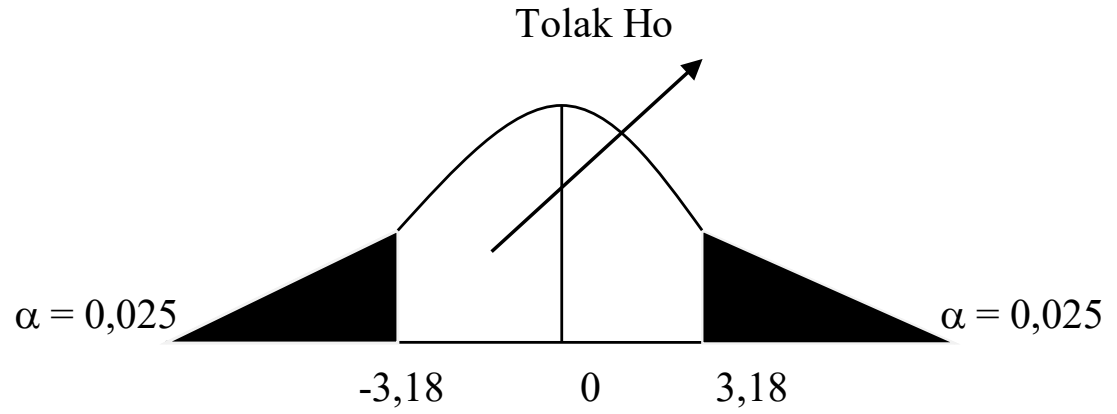

\section{Keputusan :}

Karena $\boldsymbol{t}$ hitung $>$ t tabel, maka Ho di tolak dan $\mathrm{H}_{1}$ di terima.

Artinya hiptesa yang di sampaikan oleh penulis terbukti., bahwa produktivitas tenaga kerja tinggi maka akan meningkatkan penjualan.

\section{Kendala Yang Di Hadapi Perusahaan}

Seiring dengan meningkatnya bisinis perusahaan dari tahun ke tahun, manajemen perusahaan berharap adanya kesadaran dari karyawan untuk selalu menjaga tingkta produktivitas kerja tetap tinggi dengan motivasi kerja yang tinggi juga.

Namun fakta di lapangan sering berbeda, bagaimanapu manajemen tidak menutup mata jenuh dengan rutinitas kadang bisa membuat turunnya produktivitas selain faktor lingkungan kerja juga.

Selama ini perusahaan telah memetakan dan melakukan identifikasi beberapa permasalahan yang di hadapi persauhaan sebagai berikut :

a. Adanya perbedaan persepsi antara manajemen dan karyawan berkaitan dengan target yang telah di tetapkan top manajemen

b. Faktor Subjectivitas dalam memberikan reward

c. Adanya Perubahan kebijakan manajemen perusahaan di tengah jalan

d. Faktor external ( khususnya kebijakan pemerintah)

e. Fungsi kontrol supervisor belum maksimal

\section{Kesimpulan dan Saran}

\section{Kesimpulan}

Bahwa besarnya pengaruh produktivitas tenaga terhadap penjualan mencapai $72,25 \%$ artinya masih ada faktor lainnya yang mempengaruhi tingkat penjualan. 
Dari hasil data analisa ini manajemen perusahaan bisa di jadikan bahan pertimbangan dalam membuat kebijakan di masa yang akan datang dengan memberikan reward kepada karyawan mempunyai kontribusi terbaik sesuai dengan aturan perusahaan yang berlaku dan membangun prasarana yang mampu mendukung peningkatan produktivitas karyawa. Maka penulis mengambil kesimpulan :

a. Manajemen PT 3M Indonesia dalam meningkatkan produktivitas tenaga kerja adalah dengan membuat kebijakan efesiensi pada tenaga kerja.

b. Dalam menjalankan bisnis PT 3M Indonesia tidak melakukan penjualan secara langsung kepada konsumen, namun menjual produk melalui distributor yang sudah di tunjuk. Hal ini bertujuan untuk mengahindari industri padat karya.

c. PT.3M Indonesia merupakan perusahaan modal asing ( PMA ), yang bergerak dalam bidang perdagangan yang menjual produk kualitas tinggi yang di buat dengan teknologi tinggi.

\section{Saran}

Di sadari atau tidak di sadari dalam membuat kebijakan, banyak perusahaan melihat dari sisi dominasi kepentingan perusahaan harus lebih di kedepankan.

Artinya perusahaan sebagai organisasi melihat bahwa dengan tujuan perusahaan bisa di capai, maka akan timbul dampak yang positif terhadap, stake holder dan pemangku kepentingan di dalamnya termasuk karyawan yang ada di dalam organisasi yang terlibat baik secara langsung maupun tidak langsung .

Berkaitan dengan hal tersebut, maka penulis memberikan saran kepada manajemen perusahaan:

a. Produktivitas karyawan masih bisa di tingkatakan dengan menciptakan komunikasi dua arah antara atasan bawahan.

b. Efesiensi tenaga kerja bukan merupakan cara yang terbaik dalam meningkatkan produktivitas karyawan, perlu di coba untuk malakukan pembukaan potensi pasar yang baru untuk meningkatkan penjualan.

c. Meningkatkan strategi promosi pemasaran melalui media televisi, di mana selama ini iklan yang di lakukan oleh perusahaan khususnya media TV masih belum maksimum. 


\section{DAFTAR PUSTAKA}

Agus Sabardi, 1977, Pengantar Manajemen, Gramedia Pustaka Utama, Jakarta

Amin Wijaya, 2000, Pengukuran Kinerja dengan Balanced Scorecard, Gramedia Pustaka Utama, Jakarta

Faustino Cardoso Gomes, 2000, Manajemen Sumber Daya Manusia, Gramedia Pustaka Utama, Jakarta

Husein Umar, 2000, Riset Sumber Daya Manusia, Gramedia Pustaka Utama, Jakarta

Philip Kothler, 1997, Manajemen Pemasaran, Gramedia Pustaka Utama, Jakarta

T. Handoko, 199, Dasar - dasar Manajemen Produksi dan Operasi, Gramedia Pustaka Utama, Jakarta. 